Wyższa Szkoła Nauk Humanistycznych i Dziennikarstwa, Poznań

\title{
Blogi polityków. Kto, dlaczego i o czym pisze?
}

\section{Wprowadzenie i uzasadnienie tematu}

Poruszana tematyka blogowania jest zjawiskiem, który przyniósł ze sobą rozwój techniki komunikowania ze pośrednictwem Internetu. Pierwotnie blogi używane były przez internautów niebędących politykami już na początku lat 90 . Z czasem wartość Internetu, jako narzędzia komunikacji, została zauważona także przez polityków. Dziś zarówno Facebook, Twitter czy You Tube są środkami przekazywania informacji, mobilizacji zwolenników, budowy społeczności i koordynacji dzialalności politycznej $\mathbf{w}$ świecie rzeczywistym. Te same role w różnym stopniu spełniać mogą także blogi - czyli internetowe pamiętniki lub kroniki wydarzeń.

Uzasadnienie podjęcia tematu jest wielowątkowe. Blogowanie jest zjawiskiem globalnym, powszechnym i modnym. Blogują politycy europejscy, choć prym wiodą amerykańscy, traktując Internet pragmatycznie, jako środek służący wygraniu wyborów. W obu jednak przypadkach blogi są nośnikiem idei i prezentacji sylwetki kandydata, czy to za pośrednictwem tekstu czy dźwięku (podcast). W Polsce pierwsze serwisy umożliwiające pisanie blogów po polsku (np. Onet.pl.) powstały w latach 2001-2002. Współcześnie blogi piszą zarówno przedstawiciele legislatywy, egzekutywy, a także władz samorządowych. Piszą także politycy poza strukturami ustawodawczymi i wykonawczymi oraz ci, dla których uprawianie polityki polega na wywieraniu wpływu. Pobieżna analiza danych internetowych wskazywała na to, że największą aktywnością kronikarską poszczycić się mogli politycy PO - 33 osoby, niewiele mniejszą PSL - 30 osób, SLD - 25 i najmniejszą PiS - 12 osób ${ }^{1}$. Komentując wskazane liczby, warto zwrócić uwagę, iż dotyczą one kategorii ,polityk”, która w naszym opisie nie jest tożsama z poję-

1 Liczba polityków piszących blogi według portalu blogi-polityków.com. Dane według portalu www.blogi-polityków.com z dnia 23 maja 2011. 
ciem parlamentarzysta. Warto także nadmienić, że część blogów parlamentarzystów z PO jest także nieaktaulizowana. Sugerując się natomiast danymi dotyczącymi blogowania zaczerpniętymi ze stron partii politycznych, zgrupowanymi w Sejmie w kluby parlamentarne, fakty przedstawiają się odmiennie. Najliczniejszą grupą blogującą w Sejmie są posłowie PSL-u - 16 osób, 8 z PO, 3 z SLD, brak jest natomiast danych dotyczących posłów PiS. Stosunkowo popularny jest blog wśród eurodeputowanych, dla przykładu z SLD - pisze go aż czterech deputowanych regularnie, a żaden poseł regularnie. Swoistym fenomenem blogerskim jest PSL, gdzie aż 13 posłów pisze blog, w tym także liderzy partyjni.

Blogi są przedmiotem zainteresowania nauk politycznych, w zakresie, $\mathrm{w}$ jakim dotyczą polityki. Elementem łączącym blogosferę ${ }^{2} \mathrm{z}$ polityką jest najczęściej (i także w przypadku tego artykułu) osoba polityka (osoba publiczna). Innym łącznikiem blogosfery z polityką jest oczywiście przedmiot zainteresowania blogerów - czyli polityka, rozumiana jako działalność publiczna, czyli realizacja spraw wspólnoty, a nie prywatnych interesów jednostki. Przyjęcie arystotelesowskiego rozumienia polityki nie pozwoliłoby autorce na realizację zamierzonych celów, gdyż podmiot nie zawsze podlegałby pod kategorię polityk. Blogi te umieścić możemy natomiast w ramach kategorii „,blogi polityczne” (np. Kataryna, Matka Kurka).

Wśród nauk politycznych blogi są przedmiotem zainteresowania głównie marketingu politycznego. Wynika to z faktu, że mogą być wykorzystywane jako element marketingowych strategii wyborczych. Nadto pozwalają politykowi na stały kontakt $\mathrm{z}$ wyborca, realizując tym samym zadania marketingu permanentnego. Stanowią obszerniejszą w treści wypowiedź, niż np. te zamieszczane na Twitterze. $Z$ natury więc będą przeznaczone dla internauty, który ma więcej czasu, choć pewnie i chęci na zapoznanie się z treściami tworzonymi przez polityków. Znamiennym dla zjawiska blogowania jest fakt, że częstokroć odbiorcami treści są sami politycy, koledzy z tych samych lub innych partii politycznych, spragnieni politycznego komentarza kolegi.

Trzecim argumentem uzasadniającym wagę podjętego tematu jest wartość bloga jako narzędzia dwustronnej komunikacji z wyborcami. Pamiętajmy bowiem, że internetowe pamiętniki są z założenia komento-

2 Blogosfera (ang. blogosphere) to termin określający wszystkie blogi jako społeczność lub sieć społeczną. Określenie to jest wiązane ze słowem „logosphere”, który od gr. „logos” (słowo) oznacza „świat słów”, „świat dyskusji”. Jego powszechne użycie datuje się od 2002 r. Za, www.wikipedia.pl, stan z dnia 19 września 2011. 
wane przez internautów. W ten sposób politycy uzyskują możliwość budowania nieformalnych sieci, między ludźmi myślącymi podobnie i zainteresowanych podobnymi zagadnieniami. Ten rodzaj relacji porównać można także do budowania polis na miarę XXI wieku.

\section{Metody badawcze}

Tekst powstał przy wykorzystaniu metody analizy zawartości Internetu pod kątem blogowania przez polityków. Analiza prowadzić miała do opisu zjawiska, w tym jego popularności, zawartości treściowej wybranych blogów, częstotliwości dokonywanych wpisów oraz pełnionych funkcji. Pomocna w opisie zjawiska blogowania była także metoda ankietowa. Ułożona przeze mnie ankieta wielokrotnego wyboru, złożona z kilkunastu pytań, została skierowana za pośrednictwem Klubów Parlamentarnych do posłów i senatorów VI/VII Kadencji. Oprócz stopki, w której pytałam o wiek, płeć i przynależność partyjną, do najważniejszych zaliczyć można następujące: pytanie o motywację, o częstotliwość umieszczania wpisów, tematykę wpisów, korzystanie z innych form komunikowania społecznościowego w Internecie, ocenę funkcjonalności bloga, w porównaniu z innymi formami komunikowania społecznościowego w Internecie, o czytelnictwo blogów pisanych przez innych polityków, o prowadzenie i sprawdzanie statystyki odwiedzin oraz reklamowanie swojego bloga. Umieszczenie ankiety w sieci, gwarantowało jej anonimowość.

Grupa, do której adresowałam ankietę była dość liczna, w sumie 560 parlamentarzystów (460 posłów i 100 senatorów). Pierwszy odzew na akcję wynosił 3 osoby, kolejny 5 zwrotnych ankiet. W sumie więc zgromadziłam dane od 8 parlamentarzystów. Pomimo niewielkiej liczby odpowiedzi zdecydowałam się na upublicznienie wyników ankiety w niniejszej publikacji. Pozwalają bowiem na uzupełnienie tematyki blogowania, przy pomocy danych, których nie zdobyłabym poprzez analizę zawartości treściowej blogów, np. kwestie związane z motywacją.

\section{Zakres przedmiotowy i czasowy badań}

Badania można podzielić na dwie części. W pierwszej przedmiotem badań były aktualizowane na bieżąco blogi wybranych polityków: posłów i senatorów, reprezentujących cztery największe partie polityczne obecne w Sejmie: Platformę Obywatelską RP (dalej PO), Prawo 
i Sprawiedliwość (dalej PiS), Polskie Stronnictwo Ludowe (dalej PSL), Sojusz Lewicy Demokratycznej (dalej SLD). Analizie poddane zostały tylko blogi pisane w sposób ciagły, bez znacznie dłuższych niż miesiąc przerw. Warunkiem kwalifikującym było także to, aby pisanie rozpoczęło się najpóźniej 1 stycznia 2011 r. Systematyczność dokonywanych wpisów okazała się dla niektórych blogów warunkiem wykluczającym np. dla Anny Muchy i Agnieszki Pomaskiej z PO. Warto zwrócić także uwagę na fakt, że blogi niektórych polityków przestają działać po okresie kampanii wyborczej np. blog Andrzeja Olechowskiego i Andrzeja Zawiszy. Są też blogi polityków, którzy pomimo braku czynnego udziału w polityce, piszą internetowe dzienniki np. Aleksandra Jakubowska. Warto zauważyć, iż w przypadku części posłów rolę blogu - sprowadzająca się do kroniki wydarzeń pełni strona internetowa, z relacjami z konferencji prasowych, udziału w ważnych wydarzeniach, zakładką moje poglądy, czy możliwością napisania listu etc. Do wyjątkowo czynnych blogerów z PO należy Radosław Sikorki, jego blog jest jednak pamiętnikiem członka egzekutywy, o czym świadczy analiza treściowa zawartości.

Wśród analizowanych blogów znalazł się: blog posłanki Beaty Bublewicz z PO oraz jej partyjnego kolegi także posła Andrzeja Orzechowskiego. Ponadto blog posła PSL - Aleksandra Soplińskiego, senator PO Jadwigi Rotnickiej oraz senatora z PiS Tadeusza Gruszki. Osobną subkategorię opisu tworzą blogi europosłów Marka Siwca z SLD i Ryszarda Czarneckiego z PiS.

Do przedmiotu badań nie włączono blogów polityków będących poza władzą ustawodawczą lub jak to woli prawodawczą (biorąc pod uwagę także deputowanych do Parlamentu Europejskiego). Ponadto zaznać należy, że analizie podlegały jedynie wpisy dokonywane przez samych polityków, czyli już nie np. komentarze do tych wpisów. Tym samym przedmiotem artykułu nie była analiza blogosfery, a jedynie blogów. Zakres czasowy badań, prowadzonej analizy odnosi się do okresu od stycznia do maja $2011 \mathrm{r}$.

\section{Źródła poznania}

Przy pisaniu artykułu korzystałam z danych dostępnych w Internecie, na następujących stronach: www.blogi-politykow.pl, www.gover.pl, www.blog.onet.pl, www.salon24.pl, www.beatabublewicz.pl, www.andrzejorzechowski.pl, www.jadwiga.rotnicka.blog.onet.pl, www.tadeuszgruszka.pl. 
Źródłem wiedzy do napisania części drugiej tekstu były wspomniane dane $\mathrm{z}$ anonimowej ankiety internetowej przeprowadzonej $\mathrm{w}$ dniach 19-25 maja 2011 r. i 30 maja-13 czerwca 2011 r. wśród posłów i senatorów bieżących kadencji.

\section{Kryteria wyboru obiektów do badania}

Pisząc zasadniczą część tekstu starałam się znaleźć i wybrać blogerów we wszystkich mających swoją reprezentację w Sejmie, Senacie i Parlamencie europejskim przedstawicieli partii politycznych. Istotne było więc zarówno samo fizyczne/materialne pisanie pamiętnika internetowego, ale i przynależność do partii politycznej. Wybór osobowy był natomiast wyborem subiektywnym. Część ankietowa pracy oparta jest na wszystkich informacjach zwrotnych otrzymanych od posłów i senatorów, nieograniczonych więc subiektywnie przez autorkę tekstu

\section{Blog - próba zdefiniowania}

Blog (ang. web log - dziennik sieciowy) jest rodzajem strony internetowej zawierającej określoną liczbę odrębnych, samodzielnych, uporządkowanych chronologicznie wpisów, których twórcą jest właściciel bloga. Blogi umożliwiają zazwyczaj archiwizację oraz kategoryzowanie wpisów, a także komentowanie wpisów przez czytelników danego bloga. Ogół blogów w Internecie tworzy tzw. blogosfery. Blogi najczęściej mają charakter osobisty i służą jako internetowe pamiętniki. Takie blogi zawierają osobiste przemyślenia, uwagi, komentarze, rysunki, a nawet nagrania - przedstawiają w ten sposób światopogląd autora. Blogi mają też wiele innych zastosowań: mogą być używane jako wortale poświęcone określonej tematyce, narzędzia marketingu czy komunikacji (np. politycznej). Używane są też jako strony internetowe; często opatruje się je aliasami, by darmowa strona internetowa wyglądała profesjonalnie. Autorzy blogów śledzą zazwyczaj inne blogi, tworzą do nich odsyłacze i nawiązują kontakty z ich autorami, wtedy siatka blogów zaczyna działać jako większa, powiązana całość, czyli tzw. blogosfera. W przypadku blogów poświęconych specyficznej tematyce wymiana myśli między autorami może sprzyjać rozwojowi danej dziedziny wiedzy. W przypadku blogów osobistych autorzy nawiązują często stosunki 
towarzyskie, dlatego też możemy porównać sieć blogów z aplikacjami rodzaju social networking, takich jak polskie Grono czy Facebook. Wyróżnia się kilka rodzajów blogów: mikroblog, w którym poszczególne wpisy ograniczają się zazwyczaj do jednego zdania, fotoblog gdzie podstawową treść stanowią zdjęcia fotograficzne, wideoblog gdzie podstawową treść stanowią filmy, flog-blog osobisty, którego autor jest opłacany przez przedsiębiorstwo; jego celem jest ukryta reklama produktów moblog-treść jest umieszczana za pomocą urządzenia mobilnego ${ }^{3}$.

Do tej encyklopedycznej definicji, dodać można jeszcze informację, że blogi zawierają komunikaty mniej oficjalne niż autoryzowana wypowiedź prasowa, blogi przełamują monopol mediów tradycyjnych na opisywanie rzeczywistości, bo blogowicz komunikuje z pominięciem filtra mediów. Korzystający z bloga, korzystają z przysługującej im wolności słowa, która jednak nie ma charakteru nieograniczonego. Prawo formułuje bowiem także pod adresem blogowiczów - autorów, określone wymogi dotyczące np. ochrony dóbr osobistych innych osób.

\section{Funkcje bloga}

Dotychczasowe uwagi na temat funkcji bloga można uzupełnić o następujące stwierdzenia, wynikające także z odpowiedzi ankietowych. Uznać należy, że funkcje bloga są pochodnymi motywacji autora. Jako najczęstszą motywację skłaniającą do pisania bloga parlamentarzyści wskazali: chęć wyrażenia swoich poglądów i zaznajomienia ze swoimi poglądami innych osób (70\%). Pozostałe 30\% ankietowanych traktuje bloga jako formę reklamy i autokreacji samego siebie. Przekładając motywacje na język funkcji można wskazać, że najistotniejsze znaczenie przypisują parlamentarzyści celom informacyjnym i perswazyjnym bloga. Świadczy o tym także wskazana przez nich tematyka wpisów. W zasadzie ankietowani podzieli się na dwie grupy - dla których blog jest narzędziem do opisu pracy (obowiązków, wyjazdów, sprawozdań ze spotkań) i możliwością skomentowania aktualnych wydarzeń. W ten sposób, myślę że całkowicie nieświadomie, posłowie i senatorowie wypełniają obywatelskie prawo do informacji z organów działalności publicznej. Ważne jest także to, iż pisząc bloga autorzy nie korzystają

\footnotetext{
3 Za, www.wikipedia.pl, stan z dnia 19 września 2011.
} 
z żadnych form reklamy swojego dziennika, z wyjątkiem rozpowszechniania wśród znajomych.

Lektura blogów potwierdza hierarchię tych funkcji. W praktyce najczęściej czysta informacja połączona jest z rodzajem politycznej reklamy lub innego komunikatu, który pełni funkcję z angielskiego zwaną „banner'em” - czyli sztandarem, transparentem reklamowym. Informacja ta służyć ma rozeznaniu wśród wyborców, co można uzyskać dzięki takiemu, a nie innemu „bannerowi”.

Prócz tego, warto zauważyć, że treści ujawnione w blogu mogą stać się przedmiotem dyskursu społecznego np. na łamach prasy. Przykładem takiej sytuacji są np. wypowiedzi blogera Prezydenta m. Poznania Ryszarda Grobelnego na temat zamknięcia stadionu miejskiego przez Wojewodę oraz dyskusja po tym wpisie w „Gazecie Wyborczej” z dnia 6 maja 2011 r. Filozoficznie rzecz ujmując, blogi wyłaniają nieformalne sieci ludzi myślących podobnie lub zainteresowanych podobnymi zagadnieniami, tworząc namiastkę czegoś na kształt greckiego polis. Zadaniami przypisywanymi tym greckim wspólnotom było m.in. budowanie więzi między ludźmi, wynikających nie tylko z faktu wspólnego zamieszkiwania niewielkiego obszaru, ale i wspólnych instytucji politycznych, w których brali czynny udział jako obywatele, zabierając głos. Tworzenie „wspólnot" to jedną z podstawowych funkcji politycznego bloga. Do tych wspólnot należą także politycy poza mainstreemem władzy tj. Aleksandra Jakubowska, czy Janusz Korwin-Mikke.

Warto zauważyć, że w innych systemach polityczno-prawnych (np. w Stanach Zjednoczonych) za pomocą stron, na których znajdują się blogi polityków-kandydatów zbiera się fundusze potrzebne na prowadzenie kampanii wyborczych.

Nie sposób pominać wreszcie innej istotnej funkcji bloga jako osobistego dziennika/osobistej przestrzeni, stanowiącego najbardziej intymną część wyznań. Ta funkcja najbliższa jest chyba drukowanemu lub też chowanemu do szuflady pamiętnikowi i tylko od odwagi autora zależy ile siebie chciałby odsłonić.

Blogi mogą pełnić także funkcję czynnika inicjującego proces politycznej zmiany. Rola blogów sprowadzać by się mogła do identyfikacji problemu jako politycznego (agenda), czy nawet do formułowania określonej propozycji działania politycznego. Dalej proces ten przebiegałby według schematu charakterystycznego dla tego rodzaju procesów: poprzez przyjęcie przez kompetentny organ, wdrożenie oraz jego ocenę. Także na etapie oceny można dostrzec zadania, jakie mógłby spełniać blog. 


\section{Analiza blogów wybranych posłów i senatorów}

Beata Bublewicz, jest posłanką PO, 35-letnią olsztynianką, socjolożką i anglistką. W Platformie jest od 2009 r. Na jej stronach internetowych można wyczytać m.in., że w Sejmie jest wiceprzewodniczącą Komisji Kultury Fizycznej i Sportu oraz pomysłodawczynią i współtwórcą międzyresortowego programu pilotażowego „Przeciwdziałanie poprzez sport agresji i przemocy wśród dzieci i młodzieży". Pracuje także w Komisji Spraw Zagranicznych, koncentrując uwagę w szczególności na pomocy rozwojowej dla krajów najbiedniejszych. Jest przewodniczącą Parlamentarnego Zespołu ds. Bezpieczeństwa Ruchu Drogowego, wiceprzewodnicząca Parlamentarnej Grupy Polsko-Indyjskiej, członkiem Parlamentarnej Grupy Polsko-Australijskiej i Parlamentarnej Grupy Kobiet. Przewodniczy również delegacji Sejmu i Senatu RP do Inicjatywy Środkowo-Europejskiej. Statystyki sejmowe wskazują na nieznaczną aktywność posłanki w zakresie wystąpień na posiedzeniach, interpelacji, zapytań i pytań bieżących, nie umieszczając jej w pierwszej setce najbardziej aktywnych posłów.

Bublewicz pisze blog „o rzeczach ważnych i mniej istotnych”. Jest blogerką od czerwca 2010 r. Zanotowała 13820 odwiedzin i 60 komentarzy. Nie pisze dziennika codziennie, średnio trzy razy na miesiąc, jej wpisy mają średnio ok. 1500 znaków. Tematyka związana z polityką krajową (4 wpisy), jak i międzynarodową ( 2 wpisy), nie jest dominująca. Najwięcej jest wpisów o charakterze pozapolitycznym. Dokonując analizy zawartości treści zauważyć należy, iż w zasadzie blog Bublewicz jest blogiem społecznika, zaangażowanego w sprawy np. polepszenia bezpieczeństwa w ruchu drogowym, deprawacji młodzieży, zaproszeniom na uroczystości. Tematyka międzynarodowa jest także pretekstem do uwag natury społecznej. W zapisach widoczna jest jej wrażliwość społeczna, ale i zaangażowanie w przedsięwzięcia, w których uczestniczy.

Kolejnym analizowanym blogiem był blog posła Andrzeja Orzechowskiego z PO. Urodzony w 1962 r., pochodzi z Ełku, jest z wykształcenia ekonomistą, ekspertem finansów publicznych i ekspertem z zakresu ekonomiki i organizacji ochrony zdrowia, wykładowcą w szkołach wyższych, autorem publikacji z zakresu finansów publicznych i organizacji ochrony zdrowia. Blog prowadzi od stycznia 2008 r., w sumie miał 57843 odwiedzin i 1020 komentarzy do wpisów. Orzechowski jest stosunkowo regularnym blogerem, zamieszczającym od czterech (marzec) do dziesięciu (maj) wpisów w miesiącu. Analizując treści poruszane w internetowym pamiętniku, można zauważyć że najczęściej porusza- 
nym tematem są sprawy polityki krajowej (17 wpisów), w dalszej kolejności sprawy regionu (10). Stosunkowo niewiele miejsca poświęcił sprawom polityki międzynarodowej (1 wpis). Niewiele jest też wpisów, które określam zbiorczą kategorią „różne” - tylko 1. Dla porównania u posłanki Bublewicz było ich aż osiem w analizowanym okresie.

Warto zauważyć, iż autor porusza problematykę związaną stricte z regionem, w którym zamieszkuje i z którego jest posłem, czyli Mazur. W ramach problematyki regionu na plan pierwszy wybijają się dwa zagadnienia: sprawy energetyki oraz infrastruktury drogowo-kolejowo-wodnej. Tym sprawom autor poświęcił odpowiednio 3 i 4 wpisy. We wypisach dotyczących regionu autor relacjonuje np. problematykę zmian w prawie dotyczących regionu, proponowanych planów i założeń rządu dotyczących regionu oraz swojego udziału w debatach, konferencjach etc. dotyczących regionu. Wydaje się, iż z punktu widzenia wyborcy blog tego typu może być cennym źródłem wiedzy: o aktywności posła, ale i o planach rządu dotyczących regionu i zmianach w prawie dotyczących regionu.

Autor stosunkowo rzadko porusza na blogu kwestie związane z wydarzeniami mającymi miejsce poza RP (sprawy polityki międzynarodowej), już jednak polityka zagraniczna rządu polskiego interesuje go znacznie bardziej, gdyż zajmował się tymi zagadnieniami 4 razy (zawsze w kontekście regionu).

Autor sporo miejsca na blogu poświęca sprawom polityki krajowej, jego wpisy mają charakter syntezy dotyczącej określonych polityk rządu, np. prorodzinnej, pracy, gospodarczej, społecznej, dotyczącej szkolnictwa wyższego etc. Wpisy czynione są np. z powodu zmian przepisów prawa $\mathrm{w}$ określonych dziedzinach lub z powodu planów rządu wprowadzenia określonych zmian. W tym sensie blog ten pełni głównie funkcję informacyjną, choć można i rzec, że propagandowa, jeśli chodzi o działalność rządu. Mało jest natomiast w dzienniku wpisów o charakterze politycznym (konfliktowym) - tylko 5 (dotyczyły one Jarosława Kaczyńskiego, PiS i Smoleńska).

Kolejny z analizowanych blogów należy do posła ziemi płockiej z list PSL-u Aleksandra Soplińskiego. Urodził się w 1942 r. w Ciechanowie, z wykształcenia jest lekarzem, jednak od ośmiu lat pracuje jako poseł, wcześniej także jako samorządowiec. Zasiada w komisjach zdrowia oraz polityki społecznej. Pisze bloga, od co najmniej września 2009 r., miał 223814 wejść, 24309 komentarzy, wpisy dość długie, ok. 3 tys. znaków, zdjęcia, rysunki. Statystyka umieszczania wpisów wskazuje iż średnio zamieszcza on 11 wpisów na miesiąc. Najbardziej aktyw- 
nymi pisarsko miesiącami były marzec i kwiecień. Jeśli chodzi o poruszaną tematykę to najwięcej wpisów poświęconych jest sprawom polityki krajowej (47 wpisów). W pamiętniku posła można także wyodrębnić osobną subkategorię opisu, którą nazwałam działalność poselska (12 wpisów). Sporo uwagi poświęca także polityce międzynarodowej (8 wpisów) oraz tzw. różnym sprawom. Wśród spraw polityki krajowej na pierwsze miejsce wysuwa się tematyka związana z Jarosławem Kaczyńskim i PiS-em (11 wpisów), PJN-em, tragedią smoleńską (6 wpisów) oraz własnym podwórkiem, czyli PSL-em (5 wypisów). Wartością dodaną blogu Soplińskiego jest bezwarunkowo kategoria poświęcona sprawom regionu. W ten sposób autor zdaje relacje ze sprawowanego mandatu prawie czterem tysiącom wyborców, którzy go poparli. Nadto jest to bloger zaangażowany w sprawy polityki krajowej, w tym także koalicję rządową swojego ugrupowania.

Kolejnym z omawianych blogów jest blog Jadwigi Rotnickiej, piszącej od maja 2010 r. Senator z PO miała 2166 odwiedzin i tylko 22 komentarze. Teksty są dość długie i mają ok. dwa tysiące znaków. Senator nie zagląda do dziennika jednak za często, w styczniu i marcu tylko 3 razy, w kwietniu 4 razy, a w lutym tylko jeden raz, w maju brak wpisu. Rotnicka jest profesorem na Uniwersytecie Adama Mickiewicza w Poznaniu, na Wydziale Nauk Geograficznych i Geologicznych. Od roku 1990 do 2007 była nieprzerwanie radną Rady Miasta Poznania. W Senacie jest członkiem następujących Komisji: Komisji Środowiska (do stycznia 2009: Rolnictwa i Ochrony Środowiska) oraz Komisji Samorządu Terytorialnego i Administracji Państwowej. Ponadto, jako zastępca członka, wchodzi też w skład delegacji do Zgromadzenia Parlamentarnego Rady Europy. Jest też członkiem senackiego Zespołu Wodnego, w którym pełni funkcję wiceprzewodniczącej i sekretarza. O czym pisze pani senator? Najwięcej miejsca na blogu poświęca ona sprawom polityki krajowej (7 wpisów), należą do niej następujące zagadnienia: edukacji proekologicznej, opieki nad małymi dziećmi, szkolnictwo wyższe, prawo o ruchu drogowym. Wybór tematów jest zazwyczaj podyktowany pracami legislacyjnymi w izbie wyższej - stąd blog stanowi dobre (choć nieregularne) źródło wiadomości o pracach izby i zaangażowaniu w nie posłanki. Warto zwrócić uwagę, iż w przypadku niektórych wpisów autorka pragnie użyć bloga jako forum do konsultacji pewnych problemów z wyborcami, np. problematyki przemocy w szkole.

Inny blog opisywany w artykule należy do senatora PiS - Tadeusza Gruszka. Senator ma 49 lat, ukończył studia na Akademii Górni- 
czo-Hutniczej w Krakowie. Wcześniej pracował m.in. w samorządzie miejskim. Zasiada w komisjach: Gospodarki Narodowej, Spraw Unii Europejskiej. Pisze bloga od co najmniej 1 stycznia 2011 roku, jego wpisy mają po około 1000-1500 znaków i są częste. Najwięcej wpisów autor umieścił w marcu, maju i kwietniu (odpowiednio 21, 18, 16). Motto które przyświeca autorowi, widoczne na stronie internetowej brzmi: „Dla dobra obywateli dla dobra ojczyzny”. O czym pisze senator Prawa i Sprawiedliwości? Najwięcej wpisów dotyczy polityki krajowej (58), 7 spraw związanych z polityką zagraniczną i międzynarodową. Warto zauważyć, że szczególne zainteresowanie senatora budzi polityka Rosji (aż pięciokrotnie w różnych kontekstach poruszana w dzienniku). Sporo jest też wpisów które mieszczą się w kategorii „inne” - 11. Tutaj zaobserwować można spore (6 wpisów) zainteresowanie posła działalnością mediów (GW, TVN, RMF, Marcin Meller, cenzura KRRiTV). Wśród poruszanych tematów dominuje jednak wątek polityki krajowej. Do najpopularniejszych zagadnień zaliczyć można: tematykę związaną z działalnością rządu PO, premiera Tuska i jego ministrów (38 wpisów), działalnością prezydenta Komorowskiego -8 wpisów, oraz Śląskiem w kontekście Ruchu Autonomii Śląska (3 wpisy). Z powyższej tabeli widać, iż głównym przedmiotem zainteresowania senatora $\mathrm{w}$ dzienniku jest działalność „rządu Platformy Obywatelskiej”. Senator jest krytykiem działań rządu i premiera Tuska. W jego blogu przeważają wpisy o charakterze czysto politycznej krytyki, zarówno pod adresem rządu, jak i prezydenta.

\section{Analiza blogów wybranych posłów do Parlamentu Europejskiego}

Jeden z dwóch analizowanych blogów należy do Marka Siwca, rocznik 55. Związany z polityką od początku lat 90-tych, poprzez Klub Parlamentarny SLD, najpierw z legislatywą (sejm), potem z władzą kontrolną (Członek Krajowej Rady Radiofonii i Telewizji), i egzekutywa, jako Sekretarz Stanu w Kancelarii Prezydenta RP i Szef Biura Bezpieczeństwa Narodowego. Od 2004 r. do dnia dzisiejszego poseł do Parlamentu Europejskiego, w tym także jego wiceprzewodniczący. Członek wielu komisji i delegacji Parlamentu Europejskiego. m.in. Komisji Spraw Zagranicznych i Delegacji do komisji współpracy parlamentarnej UE-Kazachstan, UE-Kirgistan i UE-Uzbekistan oraz do spraw stosunków z Tadżykistanem, Turkmenistanem i Mongolią. 
Autor nazywa blog ,komentarzami do aktualnych wydarzeń”. Blog jego odwiedziło już 769056 osób, ma też znaczną liczbę komentarzy - 44 008. Poseł od marca prowadzi blog w dwóch językach: po polsku i po angielsku. Siwiec jest regularnym blogerem, wpisy na blogu pojawiają się w zasadzie codziennie, z wyjątkiem niedziel, mają objętość od ok. tysiąca do dwóch i pół tysięcy znaków (ze spacjami). Teksty zamieszczane jednego dnia dotyczą zazwyczaj jednego tematu. Tematykę bloga podzielić można na trzy części: pierwsza dotyczyć może tematyki międzynarodowej polityki, druga krajowej, są wreszcie i takie wpisy, które polityki nie dotyczą. Sprawy polityczne stanowią główny trzon dziennika, w tym delikatną przewagę mają wpisy dotyczące polityki krajowej 52, a międzynarodowej 48.

Wśród wątków polityki międzynarodowej poruszanych w dzienniku był: wątek Jaśminowej Rewolucji w państwach Afryki północnej (11 wpisów). Autor stosunkowo dużo miejsca poświęcił też problematyce relacji Unii Europejskiej z Ukrainą (7 wpisów). Osobną kategorię stanowią wpisy autora o tematyce izraelskiej i amerykańskiej (po 7 wpisów). Analizując zainteresowania europosła sprawami polityki krajowej, można zauważyć kilka bloków tematycznych. W pierwszej kolejności Siwiec zajmuje się główną partią rządzącą, czyli (PO). W przeważającej mierze jego wpisy mają charakter krytyczny (20 wpisów). Przedmiotem krytyki najczęściej byli konkretni ministrowie, posłowie lub sam premier. Kolejną kategorię stanowią wpisy na temat polskiej racji stanu, w tym wiele jest wpisów odnoszących się wprost do działań szefa resortu spraw zagranicznych (9 wpisów). Na tym tle blado wypada częstotliwość pisania o SLD - tylko 3 wpisy i o PiS - 6 wpisów. Dla porównania na temat Wielkopolski - okręgu wyborczego posła - w badanym okresie znajdziemy tylko jeden wpis, dotyczący brukselskiej wystawy poświęconej wielkopolskim Żydom.

Czytając blog Marka Siwca można dojść do następujących wniosków: narracja jest prowadzona z zewnątrz (Bruksela), autor dystansuje się, jest osobą opowiadającą się za zdecydowaną separacją państwa od Kościoła katolickiego, prezentuje krytyczny dystans wobec polityki uprawianej w Polsce i przez Polaków, a także wobec rzeczywistości polskiej, posiada dużą wiedzę i poglądy na temat polityki zagranicznej.

Ryszard Czarnecki, to kolejny polityk, deputowany do parlamentu Europejskiego, bloger. Pisze ,pamiętnik osobisty” od 2003 r. Warto nadmienić, iż w 2008 r. Czrnecki dostał nagrodę „Rzeczypospolitej” za najlepszy blog polityczny. Czarnecki to rocznik 1963 r., z wykształcenia 
historyk, w wolnej Polsce polityk, felietonista, związany z partiami katolicko-narodowymi, potem z AWS i PiS. Najpierw poseł, w rządzie Hanny Suchockiej wiceminister kultury, przewodniczącego Komitetu Integracji Europejskiej w rządzie premiera Jerzego Buzka, mający doświadczenie w pracy w mediach, pracował także na rzecz klubów sportowych. Od 2003 r. do dnia dzisiejszego deputowany do Parlamentu Europejskiego. W 2008 r. uznany przez „The Parliament Magazine”, za najbardziej aktywnego europoseła z Polski. O czym pisze Ryszard Czarnecki? Zaskakujące jest zestawienie treści poruszanych przez Czarneckiego z blogiem Siwca. Z analizy wynika, że w dzienniku odnosi się głównie do polityki prowadzonej z Warszawy (88 wpisów). Sprawy polityki europejskiej/światowej nie stanowią przedmiotu jego osobistych refleksji zbyt często (26 wpisów). Co w szczególności stanowiło przedmiot zainteresowania blogera? Z zapisów dotyczących spraw międzynarodowych nie wynika, aby Czarnecki był specjalnie zainteresowany jakąś gałęzią stosunków międzynarodowych. Na Unię Europejską autor patrzy najczęściej przez pryzmat wydarzeń w parlamencie (5 wpisów). Z państw obcych najwięcej uwagi poświęcił Rosji (3 wpisy), jest to jednak uwaga niewiele większa niż ta poświęcona odległej Afryce (2 wpisy). W tej kategorii nie brak żartów i języka anegdot. W sprawach polityki krajowej dominują jednak podobne wątki jak u Siwca. Są to: rząd PO z Donaldem Tuskiem na czele oraz jego ministrowie (37), prezydent Bronisław Komorowski i jego współpracownicy (10), resort spraw zagranicznych i jego minister Radosław Sikorski (8 wpisów), tragedia smoleńska (9 wpisów), PiS (6 wpisów). Pisząc o polityce rządu, w tym polityce zagranicznej Czarnecki nie szczędzi słów krytyki. Stosunkowo dużo wpisów poświęconych jest obecnemu prezydentowi Bronisławowi Komorowskiemu. Dla porównania w dzienniku Siwca na temat prezydenta były tylko trzy wpisy. Warto jednak zauważyć, że istnieje wspólny trzon podejmowanych tematów. Różnica polega więc na natężeniu zainteresowania, ale i stopniu emocjonalnego zaangażowania tematem. Porównując dalej zainteresowanie obydwu eurodeputowanych sprawami międzynarodowymi, zauważyć należy, że tylko w jednym miejscu znaleźć można punkt wspólny dla zainteresowań obydwu. Jest nim sytuacja polityczna w krajach Afryki północnej. Częściowo spójne wydają natomiast kategorie UE/Europa Wschodnia i UE/Parlament, odnoszą się bowiem do funkcjonowania Unii jako instytucji, poprzez pryzmat prac parlamentu w ogólności. Są jednak takie dziedziny, które stanowią wyłącznie uprawiane poletko polityków. Dla Siwca będzie to 
z całą pewnością: Izrael, USA, a dla Czarneckiego Litwa i Rosja. W tym miejscu warto także pokazać podobieństwa między przedmiotem zainteresowania innego polityka PiS - senatora Andrzeja Gruszki i Ryszarda Czarneckiego, jeśli chodzi o politykę krajową. Zaobserwować można bowiem podobne zainteresowanie tematyką związaną z rządem Donalda Tuska i jego ministrami (33-37 wpisów) oraz prezydentem Bronisławem Komorowskim (8-10 wpisów). W mniejszym stopniu, ale interesowały senatora Gruszkę także: sprawa smoleńska (2 wpisy), polityka zagraniczna rządu (2 wpisy). Podobnie eurodeputowany umieścił także dwa wpisy na temat Śląska i Ruchu Autonomii Śląska. Podobne natężenie pisania na ten sam temat, ale co najważniejsze i treść wpisów, wskazywać mogą na podobieństwo w poglądach polityków PiS, niezależne od perspektywy oglądu rzeczywistości: Bruksela, Warszawa.

W podsumowaniu chciałam odnieść się do funkcji pełnionych przez opisane w artykule blogi. W największym stopniu realizowana jest przez nie funkcja politycznej propagandy, która jest wypadkową funkcji informacyjnej i perswazyjnej. Polega ona na przedstawianiu zagadnień związanych z polityką w formie konfliktu i walki. Druga istotna funkcja realizowana przez blogi, to autoprezentacja kandydata. W stosunkowo niewielkim stopniu, blogi realizują natomiast funkcję przestrzeni osobistej oraz funkcję informacji z działalności organów władzy publicznej. Opisywane przez blogi, a właściwie tematy wpisów nie stały się przedmiotem dyskursu w mediach.

\section{Źródla internetowe}

www.andrzejorzechowski.pl.

www.beatabublewicz.pl.

www.blog.onet.pl.

www.blogi-politykow.pl.

www.gover.pl.

www.jadwiga.rotnicka.blog.onet.pl.

www.salon24.pl.

www.tadeuszgruszka.pl.

www.wikipedia.pl. 
Politicians' blogs. Who writes about what and why?

\section{Summary}

Blogging is a global, widespread and fashionable phenomenon. While some European politicians blog, their American counterparts are in the lead in their pragmatic attitude to the Internet, approached as a means to win voters. Regardless of location, though, blogs spread ideas and present the candidate's profile, whether by means of written or spoken (podcast) text. The first services facilitating blogs in Polish (e.g. Onet.pl) appeared in 2001-2002. At present blogs are written by representatives of the legislative and executive power, as well as by local authorities. Blogs play the role of political propaganda, featuring a combination of informative and persuasive functions. They are about presenting political issues in terms of conflict and struggle. Another significant function fulfilled by blogs is to raise a given politician's profile. To a lesser extent, blogs also perform the function of personal space and provide information on the activities of the authorities. 
